\title{
ALMAN ANAYASA HUKUKUNUN SORUNLARI
}

\author{
Prof. Dr. Paul LERCHE \\ Çeviren : Asistan Dr. Irfan YAZMAN
}

\section{A. TEMEL HAKLAR DUZENININ GELIŞMESI}

\section{\$ 1. Temel Haklarmn Medenî Hukuk Alanma Yayılması}

a) Önceleri temel haklar çoğunlukla yalnız ferdin devlete kar\$̊ hakları olarak anlaşılmıştır. Bugün ise temel hakların bağlayı. cllığı çoğu halde genişletilmek istenmektedir (krş. T.C. Anayasası, m. 8). Bunun genel saiki, devlete ait olmtyan güçler karşısında da ferdin gittikçe artan şekilde korunmaya muhtaç oluşudur. Bunlar arasında önem taşıyanları, meslek ve çıkar birlikleri, gruplar ve hattâ basın v.s. gibi vatandașı yalnız korumakla kalmayıp aynı zamanda tehdit de edebilen güçlerdir.

b) Bonn Anayasası bu konuda fazla açık sayılamaz : bir yandan m. 1/III'te sadece devlet güçleri bakımından bir sınırlama ya pllırken, öte yandan münferit bazı temel haklar açıkça medenî hukuk alanına taşırılmaktadır (krş. m. 9 f. III c. 2).

c) Başlica Teoriler :

aa) Elcstrem teori :

Temel haklar aymı zamanda her vatandaşı bağlar (bu konstrük. siyon m. 9/III c. 2 v.s. ile kiyasen yapilmaktadir). Bunun pratik güçlüğii ise şuradadır : Örneğin, (özel bir kişi olan) muris, (özel bir kiși olan) tacir v.s. eșitlik ilkesi ile bağlı olacak mıdır? Eğer isteyecek olduğu takdirde özel bir firma, yalmı katolikleri veya yalnız protestanlan yahut da yalnız müsliumanlarn istihdam ede. miyecek midir? Tabiîdir ki devlet bu tür harekette serbest değildir.

Bu güçlü̈̆̈i gidermek için başvurulan yol : Eşitlik temel hakkı izole edilmiş biçimde görülmemek gerekir. Bu hak, muris, ta- 
cir v.s. lehinde (aleyhinde değil) olup eşitlik ile çatışma halinde bulunan öteki temel haklarla sınırlanmıştır : örneğin, firma lehine olarak sözleșme serbestisi konusundaki temel hak ile ve muris lehine olarak da ölüme bağlı tasarruf serbestisi konusundaki temel hak ile. O halde temel haklar birbiri karşısında tartılmalıdır; bu. na göre daha özel olan temel hakka öncelik tanınır. Tabiîki, her olayda daha özel olan bir temel hak bulunmyabilir, bu takdirde çatışan haklar birbiriyle uzlaştırılmak zorundadır.

bb) Mutavassıt teori (Alman Anayasa Mahkemesi de aşağı yukan bu görüş̧tedir) :

Temel haklar doğrudan doğruya ancak devleti bağlar. Fakat dolayısıyla vatandaşların kendi aralarındaki iliş̧kileri bakımından da önem taşırlar, çünki medenî hukuk düzeni, temel hakların değer düzeninin ışığı altında yorumlanmak gerekir. Bunun etkisi özel. likle medenî kanunlardaki belirlenmemiş bazı kavramlarda ve «genel ilkelerde» göze çarpar : örneğin, «bir kimseden belirli bir davranışın beklenebilir olması» (Zumutbarkeit), "objektif iyiniyet kuralı" (Treu und Glauben) ve "kazanılmış haklar ve çıkarlar" (wohlerstandene Interessen) gibi. Bu nedenle, bir vasiyetname, muhte. vasının ırk aleyhtarlı̀̆ını kıșkırtması halinde, medenî hukuka göre bile batıl olur. Yargı uygulamasından bir örnek : Eskiden nasyonal sosyalist olan bir film yönetmenine karşı özel boykot, aslında Alman Medenî Kanunu'nun (BGB) lâfzına göre caiz değildir. Buna rağmen Alman Anayasa Mahkemesi tarafindan, BGB'nin yorumunda, düșünce özgürlüğü konusundaki temel hakkın etkili olması sonucu caiz sayılmıştır. $\mathrm{O}$ halde burada da temel hakların biribiri karșısında tartılması gereklidir; münferit bir olayın özel șartları sosıuca etkili olmaktadır. Bu tartılmanın sağlam ve zayıf olduğu tarafları vardır.

cc) Yumuşatılmıs mutavassıt teori herhalde en doğrusudur :

Buna göre prensip olarak temel haklar sadece devleti değil, aynı zamanda amaçları ile bağdaştığı oranda devlete benzer güçleri de (örneğin, siyasal partiler, iktisadî birlikler v.s.) bağlar. Bu değișiklik dışında bu teori, yukarıda (bb)'de sözü edilen mutavassit teori ile aynidir.

Uygulamadan bir örnek: Toplu iş sözleşmelerinde (özel iş̧̧i ve ișveren örgütleri, yani sendikalar ile müteșebbisler arasında) kadın işçilere tamamen aynı bir iş için erkek iş̧̧ilerinkinden daha az ücret ödenmesi kararlaştırılmıștır. Buna karşı Federal Iş Mah. 
kemesi'nin kararı, bunu anayasaya aykırı bulmuştur. Işçi sendikaları ve işveren örgütleri bugün devlet gücüne benzer güçlerdir ve bu nedenle kanaatımca prensip olarak temel haklara tâbidirler.

\section{§ 2. Münferit Maddî Temel Hak Alanlarmm Geliş̧mesi}

a) Eşitlik ilkesi (m.3) ve kişiliğin serbestçe geliştirilmesi hakkı (m. 2/I) gibi genel temel hak normlarmm anlaşılması özellikle güiçlük yaratmiştır.

aa) Eşitlik ilkesi (krș. T.C. Anayasası, m. 12) yargı organlarınca çok çekingen olarak yorumlanmaktadır. Bu ilkenin, prensip olarak, zedelenmiș olduğu, sadece, "keyfî olarak», yani "objektifliğe mutlak aykırı nedenlerle» eşit olayların eşitsiz veya eşit olmıyan olaylarm eșit biçimde işlem görmesi hallerinde kabul edilmektedir. Ayrıca pek çok münferit güçlüklere rastlanmaktadır.

Örnek : Doğu Almanya'dan (Alman Demokratik Cumhuriyeti'nden) Batı Almanya'ya (Federal Almanya Cumhuriyeti'ne) sı̆̆ınan bir mültecinin, eskiden aktif bir komünist olması nedeniyle bașkalarından daha az elverișli bir ișleme tâbi tutulması caiz midir (krş. Bonn Anayasası, m. 3/III)?

Erkek ile kadının eşit haklara sahip olması oldukça radikal bir biçimde gerçekleştirilmiştir (krş. Bonn AY, m. 3/II). Örnek : Karı koca (örneğin, çocuğun iyi eğitim görmesi konusunda) anlaşamadıkları takdirde, artık kocanın tek başına karar verme yetkisi yoktur.

bb) Kișilik özgürlüğünün (Bonn $\mathrm{AY}, \mathrm{m} .2 / \mathrm{I}$ ) yorumunda ise, yargı organları uygulaması başka bir yol izlemiștir. Bonn Anayasası'nın 2. maddesinin I. fıkrası şöyledir : «Herkes, başkalarının haklarını ihlâl etmediği ve anayasal düzene veya ahlâk kurallarına ay. kırı düșmediği oranda, kendi kişiliğini serbestçe geliștirmek hakkına sahiptir». Başlangıçtaki tereddütlerden sonra bugün Alman Anayasa Mahkemesi, «kişiliğin serbestçe geliştirilmesi» deyimi aItında, ferdin en genel anlamda eylem serbestisini, yani istenilen herşeyi yapmak veya yapmamak konusundaki özgürlügüunüi anlamaktadir. Bu özgürlük vatandaş tarafından çoğunlukla lüzumundan fazla başvurularak kötüye kullanılmaktadır. Örnek: Gece kulübüi dansözleri, giyim konusundaki zabıta hükümlerine karşı Bonn Anayasası'nın 2. maddesinin I. fıkrasına başvurmuşlardır. 
Bu nedenle Alman Anayasa Mahkemesi, Bonn Anayasası m. 2/I'in smurlarımı buna uygun genişlikte, yani devlet için daha elverişli bir biçimde, yorumlamak zorunda kaldı : Buna göre, her alelâde kanun, diǧer bakımlardan da anayasaya uygun olduğu takdirde m. 2/I'deki özgürlük temel hakkmı otomatik olarak sınurlayacaktır. $O$ halde kişi ancak kanunlar çerçevesinde her istediğini yapmak ve yapmamak özgürlïgüne sahiptir.

Bu yargı uygulamasının sonucu şu oldu : Madde 2/I kanun koyucu karşısındaki değerini fiilen kaybetmiștir, «boşuna işlemektedir», gerçek bir temel hak değildir. Çünki gerçek temel haklar bugün sadece icrayı değil, asıl kanun koyucuyu bağlamaktadır (krş. Bonn Anayasas1, m. 1/III).

Bunun içindir ki, Bonn $\mathrm{AY}$ m. 2/I'in bu uygulaması şiddetli eleştirilere konu olmuştur. Gerçekten bu uygulama bir yandan vatandaşa pek çok şey verirken, öte yandan verdiği şeyin hemen ta. mamın geri almaktadir.

b) Özellikle dikkati çeken başka bir gelişme de, iktisadm belirlediğı temel haklarm gelişmesidir : herşeyden önce mülkiyet temel hakkı (Bonn AY, m. 14; krş. T.C. AY m. 36-39) ile meslek öz. gürlügü hakkmdaki (Bonn AY, m. 12) gelişmede olduğu gibi.

\section{aa) Mälkiyet hakkı konusunda :}

$\mathrm{Bu}$ geliş̧me içerisinde «mülkiyet» çok geniş anlaşılmaktadır (daha I. Dinnya Savaşı sonunda beliren bir akımın devamı olarak). "Mülkiyet" sadece taşınmaz ve taşınabilir eşya üzerindeki hakları değil, aynı zamanda mamelekî değeri bulunan ve özel hukuktan doğan her hakkı da (örneğin, patent hakların, alacak haklarını v.s. da) kapsamaktadır; hattâ bazıları sübjektif kamusal hakları dahi bu kapsama sokmak istemektedirler (örneğin, memurların maaş haklarinı).

Bu genişlemenin saiki şudur : Eskiden Almanya'da esas itibariyle sadece taşınmaz eşya mülkiyetinin devlet müdahalesine maruz bulunmasına karşıllı bugün Almanya'da devletin mamelek alanuna müdahalesi eskiye göre çok daha kapsamlıdır. Buna hukukî bir tepki olarak da mülkiyet kavramı aynı oranda genişletilmiştir.

Bütün bu hakların skamulaşturılması halinde stazminat" ödenmesi zorunludur. Prensip olarak böyle bir tazminat ancak satış değeri $=$ piyasa değerine (krș. T.C. AY, m. 38) uygun olduğu takdirde «âdil» (krş. Bonn AY, m. 14/III) olarak kabul edilmekte- 
dir. Mamafih Alman Anayasa Mahkemesi, daha geniş bir çerçeveye de cevaz vermektedir. Bir "kamulaștırma»nın ne zaman sözkonusu olduğu ötedenberi çok tartışmalıdır. Alman Yargıtayı́na göre önemli olan husus, ilgili kimsenin kamuya oranla «özel bir fedakârlık" altına girip girmediği, başka bir deyişle, eşit olmıyan bir işleme tâbi tutulup tutulmadı̆̆ıdır. Bu takdirde tazminat, eşitliği tekrar kurmak anlamına gelmektedir. Alman Danıștayı'na göre ise, önemli olan husus, müdahalenin özel bir yoğunluğa ulaşıp ulaşma. dığıdır. Bunun nedeni şöyle açıklanmaktadır : Modern kanunî tedbirler çoğunlukla belirli bir nüfus grubunu hedef almakta, ne tüm kamuyu ne de tek bir ferdi hedef almamaktadır.

Kamulaşturmaya karşı korunmanm çok yönlii olarak genişletilmesi : Bir yanda, çoğu zaman sadece dolayısıyla yapılan müdahaleler, hattâ bazı özel hallerde devlet tarafından yapılan "țavsiyeler» dahi kamulaştırma olarak görülürken, öte yanda, kamulaştırmanın bașkaca özelliklerini arzettikleri takdirde, hukuka aykırı (kusurlu veya hattâ kusursuz) tedbirler de tazminatı gerektiren birer kamulaştırma olarak ele alınmaktadır. Böylece bir idare gö. revlisinin kusurunun ispatı geniş çapta gereksiz kalmaktadır. Halbuki eskiden 34. maddeye göre idarenin sorumluluğu için kusurun ispatı zorunlu idi.

Gene de bugün, devletin kendisi tarafından sebebiyet verilen her zarardan dolayı sorumlu olduğuna dair genel bir anayasa hükmü mevcut değildir.

bb) Esas itibariyle yeni bir temel hak olan Meslek özgürlüğü konusundaki temel hak (Bonn AY, m. 12) özellikle giuç sorunlar ortaya çıkarmıştır. Bu hak önceleri çok serbest bir şekilde yorumland. Fakat Alman Anayasa Mahkemesi, mesleğin serbest olarak seçimi için de sınırlar çizmektedir. Bu sınırlar tabî̂dir ki, münhasıran "meslek» kavramına getirilmemektedir. Gerçekten, ferdin ya. şama tarzı ile ilgili her faaliyeti veya «sosyolojik" bir "meslek görünümü»ne uygun her faaliyeti "meslek" olabilir. Başka bir deyiş. le, "yüksek» ve "aşağı» faaliyetler diye bir ayırım yapılamaz.

Aksine, mesleğin serbestçe seçimine konulan sınırlar daha çok yazılı olmıyan esaslardan çıkmaktadır. Anayasa'nın başka hiçbir hükmünde görülmedik şekilde Alman Anayasa Mahkemesi bu hükümde Anayasa'nın lafzından tamamen ayrılmıştır. Yüksek Mahkeme'nin bu konudaki içtihadına göre, ancak aşağıdaki iki şartın varlığı halinde kanun koyucu bir meslegin icrasını sınırlyyabilir: 
1. Sınırlayıcı kanun, kamunun çok önemli çıkarlarına hizmet etmelidir (Örnek : halk sağlı̆̆ çıkarma olarak hekimlere ruhsat verilmesi),

2. Sınırlayıcı kanun, elverişli yollar içerisinden, vatandaşa en az yük yükleyen yolu seçmelidir; başka bir deyişle en Ilımlı yoldan gitmelidir.

Bu nedenle artık, bir mesleğin icrasım, sırf sözkonusu olan yerde ayn meslekten yeteri kadar kimsenin faaliyette bulunduğı nedeniyle yasaklamak, genel olarak caiz değildir. Bu görüş, özellik. le eczacılar, ulaşimla ilgili meslekler v.s. bakımından önem kazanm!ştır.

Üniversite öğreniminin sımırlanmasında sorun daha da güçleşmektedir (meslek özgürlüğü, aynı zamanda öğretim yerinin de serbestçe seçilmesini kapsamaktadır). Bu tür sinırlamalar ancak dış etkenler nedeniyle mümkün olup (örneğin, laboratuvarlarda yeteri kadar yer bulunmaması gibi), gelecekteki meslek seçimine yön vermek amaciyla yapılamaz.

c) Nihayet, haberleşme ile ilgili temel haklar da (özellikle düşünce özgürlü̈̆ü, Bonn $\mathrm{AY}, \mathrm{m}$. 5; Toplantı özgürlüğü, Bonn $\mathrm{AY} \mathrm{m}$. 8; Dernek kurma özgürlüğü, Bonn AY m. 9; Basın özgürlüŭüu, Bonn AY $\mathrm{m}$. 5) hukuk öğretisi ve uygulamasımın dikkatlerini üzerinde topladı̆̆ı bir merkez haline gelmiştir.

Bonn Anayasası'ndaki normlara T.C. AY'ndan çok daha kısa olduğu halde, bu alandaki tartışmalar bu hakların konularının ne olduğundan çok (örneğin, bir «basm» ürününün ne zaman mevcut sayılacağı gibi), bu hakların doğru olarak smurlanmasma değgindir. Tartışma, daha çok haberleşme haklarına sürekli bir sımır çizen "genel kanunlar" (krş. Bonn AY m. 5/II) kavramının doğru bir şekilde tanımlanması etrafındadır.

Başlica teoriler :

"Genel kanunlar» öyle kanunlardır ki, bunlar belirli özel bazı düşünceleri bastırmak istemeyip, aksine herșeyden önce başka hedeflere yönelmişlerdir ve bu arada sadece dolaylı olarak düșünce özgürlïgünü (basın özgürlüğü v.s.) sinırlarlar. «Genel bir kanun»a örnek : bir matbuanın sorumlu naşirinin herzaman beyan edilmesi gereği. 
Ikinci ana teori :

"Genel kanunlar» öyle kanunlardır ki, bunlar kamunun hukuken korunan çok önemli varlıklarmi teminat altına almak isterler. Başka bir deyişle, bunlar düşünce özgürlüğ̈ünden bu vesileyle iste. dikleri fedakârlığa oranla «daha yüksek değeri» haizdirler. Örnek Devlet sırları çıkarına olarak basın özgürlüğünün sınılanması. Burada sınırlama güçlïkleri ile karşılaşılır.

Alman Anayasa Mahkemesi, her iki teoriyi bağdaştırmıştır :

Önceden sansür mutlak surette yasaktır. Bilgi verme özgürlïgü (information) de açıkça teminat altına alınmıștır (Bonn AY m. 5/I). Bu konuda T.C. Anayasası m. 22 ile paralellik vardır. Türk dïzenlemesi çok daha açıktır; yalnız anlaşılmayan husus, T.C. Anayasasi $\mathrm{m}$. 22/II, III anlaminda "cezayı müstelzim fiiller»in ne olduğudur.

§ 3. Genel gelişmeler çizgisinin devamı : Temel hakların sübjektif hak muhtevasindan «kurumsal» muhtevasma doğru.

1945'i hemen izleyen yıllarda temel haklar daha çok münferit sübjektif haklar (özel dereceye sahip) olarak anlaşllıyordu. Halbuki bugün bunların «kurumsal» $=$ objektif muhtevaları ön plana çıkmaktadır : Temel haklar artık aynı zamanda sosyal dünya bakımından objektif değer yarglan ve prensip normlan olarak anlaşlmaktadır.

Bu görüş̧ özellikle m. 12 (meslek özgürlü̆̈̈ü) ve m. 14 (mülkiyetin korunması) için geçerlidir. $B u$ hüikümler aynı zamanda objektif bir sosyal düzeni garanti etmektedir. Örneğin, vatandaşın sadece münferit ("sübjektif») mülkiyet hakkı değil, aynı zamanda bir hukukî kurum olarak mülkiyet korunmaktadır.

Eskiden bu «kurumsal garantiler» teorisi münferit anayasa normlarına münhasırdi; örneğin, profesyonel memuriyet, beldesel özerk idareler gibi. Bunun kapsamı bugün azamî derecede genişletilmiştir. En yeni teorilere göre, her temel hak «kurumsal» bir muhtevaya, başka bir deyișle, tipik bir objektif temel öze sahiptir. Bu muhteva, temel hakkın «özï» (mahiyetini belirleyen muhtevası = Wesensgehalt) yani "çekirdełì ile özdeștir. Buna ise, Bonn Anayasası'nm 19. maddesinin II. fıkrasına göre hiçbir kanun dokunamaz (krş. benzer nitelikte : T.C. Anayasası m. 11/II). 
Örnek : Toplant1 özgürlügünün özü (Bonn AY m. 8), bütün toplantılarda belirli bazı siyasal konuların tartıṣılması yasak edilecek olduğu takdirde, ihlâl edilmiş olur.

Yahut : Bilim özgürlüŭünün özü (Bonn AY m. 5/1II), devletin üniversitelerin özerkliğini mutlak olarak kaldırması halinde ihlâl edilmiş olur.

\section{§ 4. Vatandaştaki güven duygusunun korunmasınm daha yüksek değerlendirilmesi}

a) Hukuk devleti yalnız münferit maddî muhtevaları (özellikle münferit temel hakların varlığı) ile tekeffül edilmez, ayn zamanda özellikle daha çok şeklî ve genel bakımdan da tekeffül edilir. Bugünkü alman anayasa hukuku en önemli şeklî muhtevalardan biri olarak vatandașın güveninin korunması düşüncesini kabul eder. Bu düșünce pek çok sorunu da beraberinde getirir :

b) Bonn Anayasası metninde bu konuda zayıf ve tek tük dayanaklara rastlanır : örneğin Bonn AY m. 103/II. Fakat bu konudaki içtihatlar çok zengindir (özellikle: Alman Anayasa Mahkemesi’nin yön verici nitelikteki kararları, Alman Danıstayı'nın ve Bavyera Anayasa Mahkemesi'nin kararları). Bu konu özellikle aşağıdaki sorunlar bakımından aktüel olmuştur :

c) Doğrudan doğruya makable şamil (yük tahmil edici) kanunların sinurlanması :

aa) Kanunların doğrudan doğruya makable şiumulü ceza hukuku alanında mutlak surette imkânsızdır (Bonn Anayasası, m. 103/1I; halen tartışılmakta olan sorun, Nazi dönemi cürümlerine ait zamanaşımı sürelerinin uzatılması ile ilgilidir).

bb) Bunun dışında makable şamil kanunlar, vatandaşın geriyc yürümenin başladığı tarihte böyle bir kanunun çkmasına göre "kendini ayarlamasına ihtiyaç bulunmadığı" hallerde, bașka bir deyişle, vatandașin mevcut hukukî durumun devam edeceğine "güvenmesimne cevaz olduğu hallerde, çıkarılamazlar.

Alman Anayasa Mahkemesi'ne göre aşağıdaki durumlarmn varlı̆̆ı halinde isttsnaî olarak makable șümul mümkündür :

Vahim sonuçlar doğurabilecek bazı vuzuhsuzluklar sonradan yapılan bir değişiklikle düzeltildiği takdirde (bu husus özellikle verg̣i hukukunda önem taşır); veya, kamu yararının gerektirdiği zorlayıcı sebepler makable şümulü zorunlu kıldığı takdirde. 
d) Esas itibariyle hâlâ çözümlenememiş bulunan sorun, dolayısıyla ("fiilen») makable şümul ile ilgili olanlardır :

Örnek : (X) Ulkesi'ne yapılacak ihracatla ilgili ilişkileri teşvik için kanunla vergi kolaylıkları getirilmektedir. İlgili alman müteşebbisleri kendilerini buna göre ayarlamakta, yatırımlara v.s. ye girișmektedirler. Dış politikadaki bir dönüşle ilgili olarak kanun koyucu vergi kolaylıklarını aniden (fakat doğrudan doğruya makable samil olmaksızın) kaldırmaktadır. Bu caiz midir? Tabiî ki, evet. Peki bu durumda artık avantajını kaybetmiş olan yatırımlar v.s. için bir tazminat gerekecek midir? Burası şüphelidir. Çünki aksi halde, sanayi ile uğrașan vatandașın maruz kalabileceği her riziko kaldırılmış olacaktır.

e) Bu güven prensibinden geliştirilen bir himaye șekli de, kanun hükümlerinin kazaî yorumunda aniden ortaya çlkabilecek bir değişikliłge karşı vatandaşın korunmasıdır (özellikle ceza hukukunda önemli).

f) Güven prensibinin özellikle önem tașıdığı bir konu da, yasama erkinin delegasyon yoluyla icraya havale edilmesidir (kanun kuvvetinde kararname çıkarılması konusunda hükûmete yetki verilmesi, krş. T.C. Anayasası, m. 107) : Bonn Anayasası'nın 80. maddesinin I. fikrasının 2. bendine göre, bu yetkinin muhtevas1, amac1 ve kapsamı kanunda «belirtilmelidir». Alman Anayasa Mahkemesi'nin bundan çıkardığı sonuca göre, vatandaş, tarafından «bu yetkinin hangi hallerde ve hangi ełillim içerisinde kullanılacağı ve kanun kuvvetindeki kararnamelerin hangi muhtevaya sahip olabilecekleri önceden tahmin edilebilir». Bu sebeple, șimdiye kadar kanun koyucu tarafından bu alanda verilmiș olan yetkilerin pek çoğu, belirli olmadıkları gerekçesiyle, anayasaya aykırı bulunmuştur. Özellikle, «kanun yerine geçer, kanunu temsil eder nitelikteki kararnameler» caiz değildir. Güven prensibi burada önceden tahmin edilebilme prensibi hüviyetini almıştır.

\section{§ 5. Vatandaş İçin Usul Hukuku Himayesinin Takviyesi}

a) En önemli hukukî dayanaklar şunlardır :

aa) Devlet güicünün her türlü fiil ve işlemlerine karşı hukukî himaye (dava) yolunun açklığ genel olarak Bonn AY m. 19/IV ile sağlanmıştır (krş. T. C. AY m. 114 ve 31). Bonn Anayasası'nın 19. maddesinin IV. fıkrası hükmii şöyledir: "Bir kimsenin 
devlet gücü tarafindan haklarının tecavüze uğraması halinde, kendisine dava yolu açıtır. Başkaca bir merciin görevine gir* mediği nisbette, adlî kaza yolu mevcuttur». (*) "Devlet gücü» deyiminden prensip olarak anlaşılmak gereken șey herhalde sadece icra gücü olacaktır (yasama ve yargı erklerinin de olup olmadığı tartıșmalıdır). Fakat icra gücüne askerî güç de dahildir. En son içtihatlar (özellikle Alman Danıştayı'nın içtihadı) bu lâfzın da üstüne çıarak, Bonn AY m. 19/IV'te sadece dava yolu temin edilmekle kalınmadığı, aynı zamanda gerçekten işleyen $=$ etkili = özellikle vaktinde harekete geçen bir yargı himayesinin de sağlan. dığı görüșündedir. Örnek : Çok kısa tutulan itiraz ve dava süreleri m. 19/IV'e aykırıdır. Bu ise çok uzun süren mahkeme kademeleri silsilesi problemini ortaya çıarır.

Anayasa lâfzının üstüne çıkarak yapılan başka bir kapsam genişletilmesi : m. 19/IV'ün sadece devlet gücünün yaptığı müdahalelerde deģil, ayn zamanda devlet gücüne benzer güçlerin (birlikler, basin v.s.) müdahaleleri halinde de uygulanmasi. Bu uygulama, temel hakların bağlayıcılığı sorunundakine benzer sorunlar ortaya çıarır.

bb) Bonn Anayasası m, 103/I : Adlî usulde «Mahkemeye bașvurma ve mahkeme tarafından dinlenme" hakkın belirtmektedir. $\mathrm{Bu}$ hüküm yargı içtihatlarında geniş yorumlanmaktadır. Bu sebeple m. 103/I'de bir defa, tarafların "eşit silâhlara sahip olması" prensibi (eșitlik temel hakkı ile bağlantılı olarak) ve ayrıca taraflar için verilecek kararın bir "sürpriz» teşkil etmemesi düşüncesi (güven prensibi ile bağlantılı olarak) vardır.

Tartışmalı pek çok münferit sorun vardır : Örneğin, yargıç muhtemel bir içtihat değişikliği konusunda önceden tarafların dikkatini çekmek zorunda mıdır? Devletin korunması yararına bazı ispat vasıtalarının (tanıkların) açıklanmaması caiz midir? Yargıç, taraflarla bir «hukukî diyalog»a girmek zorunda midır? Yabancılar bakımından bir tercümanın hazır bulundurulması konusunda Anayasa tarafından teminat altına alınmıs bir hak mevcut mudur?

Anayasa lâfzının üstüne çıkılarak yapılan bu kapsam genişletilmesinin getirdiği sonuçlardan biri đe, "mahkemeye başvurma ve mahkeme tarafından dinlenme hakkının sadece adlî usulde değil aynı zamanda çoğu halde idarî usulde de temin edilmesi zorunlugudur. Bunun smırının tesbiti güçtür. Fakat her halde, adlî kaza-

(*) Bu hüküm sonradan değiştirilmiştir. 
ya benzer şekilde dïzenlenmiș idarî usullerde de bunun sağlanması gerektir (Alman Danıștay).

Bu konu özellikle planlama hukukunda (örneğin, büyük yapı ve tesislere müsaade edilmesi) ve kartel hukukunda (iktisadî gụ̧̈ sayesinde büyüik piyasa temerküzlerinin kanunla sınırlanması); daha genel bir ifadeyle, iktisadî idare hukukunun pek çok alanlarında önem taşır. Bu alanlarda vaktinde mahkemeye başvurabilme, özellikle (sonradan) vâki olabilecek bir kazaî himayenin çok geç kalması sebebiyle önemlidir (Ísviçre'deki en son yargı içtihatları da böyledir).

Örnek : Bir baraj bir kere izin alinip yapıldı $\mathrm{ml}$, bunu artık yargıç hükmü ile de olsa yıkmak çok zor olacaktır, hattâ bir komşunun (haklı) itirazı haksız olarak ihmal edilmiş olsa bile. Bu sebeple, komşu için önceden mahkeme tarafmdan dinlenme hakkının bulunması elzemdir.

Bunun içindir ki, (Scheuner'e göre) Bonn Anayasası m. 103/ I'in m. 19/IV ile ve başkaca Anayasa normları ile bağlantıl olarak «due-process-of-law» şartının bir nevi almanca mütekabilini sağladığı sonucuna varılabilir.

b) Buna karșllk anayasaya aykurılık davası Anayasa tarafından temin edilmemiş olup, daha ziyade alelâde bir kanuna istinad eder. $\left(^{*}\right) \mathrm{Bu}$ dava, temel haklarm ihlâli sebebiyle, bundan doğrudan doğruya müteessir olan vatandaş tarafından Anayasa Mahkemesi'nde açllabilir. $\mathrm{Bu}$ dava, sadece yürütmenin değil aynı zamanda yasama ve yargının da tasarruflarına karșı açılabilir. Başka bir deyișle, gerektiği takdirde doğrudan doğruya kanunun kendisine karşı da açılabilir.

Ancak bunun ön şartı, daha önce bașvurulması caiz olan bü. tün diğer hukukî yollara başvurularak bir sonucun alınamamış olmasıdır. Ayrıca bugün anayasaya aykırılık davası (kanunda yapılan bir değişiklik sonucu) fiilen artık sadece kamuyu ilgilendiren bir önem taşıyan veya bu yola başvurmadı̆̆ı takdirde davacının büyük bir sakıncaya maruz kalabileceği hallerle sınırlanmıştır. Onun için bugün bazı hallerde, çok haklı gerekçelere dayanan anayasaya aykırılık davalar dahi reddedilebilir. Bundaki saik, Alman Anayasa Mahkemesi'nin gereğinden fazla işe boğulmamasını sağlamaktır.

(*) Yapılan değişiklik sonucu bugün artık Anayasa hükmü haline gelmiştir : Bonn AY m. 93/I No. 4 a GG. 
Bundan bağımsız olarak, vatandaşın federe devletlerin (Länder) Anayasalarma uygun olarak bu devletler anayasa mahkemelerine başvurma imkânı vardır. Hattâ Bavyera'da "halk davası" (Po. pularklage) denilen dava yoluyla, hiç ilgisi olmuyan vatandaşlar bile anayasaya aykırı hükümler hakkında dava hakkına sahiptirler.

Özet olarak söylemek gerekirse, vatandaşın bugün dava yoluyla sahip olduğu himayenin fevkalâde güçlü bir şekilde gelişmiş olduğu ifade edilebilir : bu, "hukuk devleti»nden "adlî devlet»e bir dönüşümdür. Bu gelişmenin tehlikesi özellikle, siyasetin hukukîleştirilmesidir. Fakat, Alman Anayasa Mahkemesi şimdiye kadarki uygulaması ile, akıllıca bir ihtiyathlık sayesinde (Amerika'daki Yüksek Mahkeme'nin "self-restraint" prensibine benzer tarzda) otoritesini muhafaza etmesini bilmiştir. Hükûmet şimdiye kadar Anayasa Mahkemesi'nin kararlarına uymuştur. Bu sebeple Anayasa Mahkemesi'nin itibarı çok büyüktür.

\section{B. TEMEL HAKLAR DUZENII DIȘINDAKİ GENEL SORUNLAR}

Bu alanda özel bazı sorunlar dışında ilk planda sözü edilen sorunlar federal devletle ilgili olanlarıdır ki, bunlar Türkiye bakmindan herhalde pek az ilgi çekici olsa gerektir. Ayrıca üzerinde durulacak konular sırasıyla : siyasî partilerin hukukî durumu, seçim hakk1, iktisadî anayasal düzen, kanunların mahiyeti, kuvvetler ayırımı sistemi içerisinde yasama kuvvetinin yeri ve son olarak da Almanya'nun uluslarüstü veya uluslararası örgütlere girmesi ile ortaya çıkan anayasal sorunlardır. Bunlar arasından aşağıdaki konulara değinilecektir :

\section{§ 6. Iktisadî Anayasal Düzen Sorunu}

Bonn Anayasası'nın iktisatla ilgili münferit düzenleyici hükümlerinin çokluğu karșısında bunlara bir bütün olarak bakıldığı takdirde, bütün bu hükümlerden anayasa hukuku tarafından öngörü̈lmüş belirli bir iktisat düzeninin çıkartılıp çıkartılmıyacağı sorusu akla gelir.

\section{Başlica Teoriler :}

a) (Erhard'ın anladığı anlamda ve halen uygulanmakta olan) "sosyal piyasa iktisadı" anayasa hukuku tarafından emredilmiştir. $\mathrm{Bu}$ teori, bir yandan daha çok liberal nitelikteki bazı Anayasa hüi- 
kümlerinin (örneğin, m. 2/I, 8/I, 9/I, 12/I v.s.), öte yandan daha çok sosyal Anayasa hükümlerinin (örneğin, m. 14/II, III, 15 v.s.) birarada mütalâa edilmesi ile kurulmuştur. Bu teoriye yapılan itiraz şöyledir : Bu teori sonucu kanun koyucunun iktisadî alandaki hareket serbestisi çok daraltılmış olur. Halbuki, örneğin bir hükûmet değişikliğinde, sosyal piyasa iktisadından uzaklaşılması da mümküin olmalıdır. Bu itiraza karşı yapılan savunma: Sosyal piyasa iktisadı sistemi kendi içinde yeteri kadar geniş ve esnektir.

b) Başka bir teori : Bonn Anayasası ne bizzat belirli bir iktisadî ideolojiyi benimsemiştir ne de buna cevaz verir. $O$ halde, iktisadî kanunlar sürekli olarak ideolojiden bağımsız olarak çıkarılmalıdur. Halbuki uygulamada bunun gerçekleștirilmesi hemen hemen imkânsızdır.

c) Başka bir teori : İktisatla ilgili her kanun hem liberal hem de sosyal nitelikleri kendinde birleștirmelidir. Bu teori ile de kanun koyucudan çok fazla şey talep edilmektedir.

d) Hâkim teori; (Alman Anayasa Mahkemesi de aşağı yukarı bu görüştedir) : Anayasa sadece (takribî) bir çerçeve çizmiş olup, kanun koyucu iktisadî konularda da bu çerçeve içerisinde serbest. çe hareket edebilir. Demek oluyor ki yalnız ekstrem sınırlar tesbit edilmiş olup, bunun içerisinde iktisadî pólitika ile ilgili karar vermek serbesttir. Bu sebeple, örneğin (ekstrem olmamak kaydıyla) "planlı iktisat» sistemine de geçmek Anayasa'ya aykırı düşmez. Fakat gene de vatandaşlar prensip olarak "sürprizlere" maruz birakılmamalıdır. Bunun için de, geçiş hükümleri, ağır mağduriyetleri kaldırıct düzenlemeler v.s. zorunludur. Illeri sürülen bu taleplerin gerçek sebebi, vatandașın güvenini korumak prensibidir (bundan yukarıda söz edildi).

\section{§ 7. Anayasa Hukuku Açısından Kanunun Mahiyeti Meselesi}

Halâ ağır basan bir görüşe göre (anayasa hukuku açısından) kanun, «vatandaşun özgürlü̈̆̈üne ve mülkiyetine yapilan müdahalelerin» dayanağı olarak belirlenir. Bu kanaatın kökü 19. yüzyıla kadar uzanır, o zamanın şartlarına ve özellikle devlet ile toplum arasunda yapılan ayırıma ve bu ayırımın devleti esas itibariyle yal$\mathrm{n} ı$ polis müdahalelerinè münhasır kılmasına («Gece bekçisi devleti») dayanır. Buna paralel olarak gene 19. yüzyılda "idarenin kanuna uygunlư̆u prensibi teşekküil etmiștir; șu anlamda ki, idarenin (özellikle polisin) külfet altına sokan tasarrufları mutlaka kanưnî bir temele dayanmalıdır. 
Bugün hâlâ temel haklarda "kanunu mahfuz tutma» teorisi bu fikre dayanır. Bunun iki anlamı vardır : Temel haklar gerçi belirli bir ölçüde sinırlanabilir, fakat öte yandan bu sinırlama için kanunî bir dayanağın olması zorunludur.

Bugün gittikçe taraftar toplayan daha yeni bir görüş kanunun mahiyetini kısmen farklı bir șekilde görmektedir. Buna göre önemli olan, özgürlüğe veya mülkiyete bir müdahalenin yapilmasından çok, muhteva itibariyle ağır basan $=$ temel teşkil eden bir tasarrufun yapılmasıdır. İște bütiin bu temel teşkil eden tasarruflar için (ve yalnız bu tür tasarruflar için) kanun gereklidir; hattâ bu tasarruflar sadece külfet tahmil edici değil, vatandaşlar için bazı kolaylıklar getirici mahiyette olsalar bile bu böyledir.

Bu bugün özellikle şu sebepten dolayı önem tașır: modern devlet faaliyetinin büyük bir kısmı vatandaş yararınadır, örneğin sübvansiyonlar, iaşe yardımları v.s. de olduğu gibi. Bu tasarruflar çoğu halde en azından müdahale mahiyetindeki tasarruflar kadar «önemlidir». Bu sebepledir ki, bu görüsse göre, devletin yardımcı faaliyetleri için de kanun șekli gereklidir.

Öte yandan, «kanunun» yalnız temel teşkil edici tasarruflara irca edilmesi ile parlamento da daha az önem tașyan işlerden kurtarılmıș olacaktır. Böylece parlamento faaliyetini kendi asıl çalışma alanında, yani sadece temel esaslar vaz etme konusunda temerküz ettirebilecektir. Bu sebeple hakh olarak, bütçenin tesbiti işi bir kanuna bırakılmaktadır (halbuki burada vatandaşın özgüılüğïne ve mülkiyetine bir müdahale sözkonusu de ğildir). Diğer taraftan, daha çok teknik mahiyetteki parlamento faaliyetleri idarî mercilere devredilebilmelidir.

Kanunun mahiyeti hakkındaki görüşlerden hiçbiri, tabiatıyla şu gerçeği görmezlikten gelememektedir: Kanun bugün gittikçe artar șekilde gerçekten genel ve sürekli düzenlemeler olmak karakterini kısmen kaybetmekte ve hele iktisadî alanda, sınırlı bir muhatap çevresine hitap eden sadece geçici bir «tedbir» mertebesine inmektedir ("Tedbir kanunlan" denilen kanunlar). Fakat gene de, Bonn Anayasası'nın 19. maddesinin I. fikrasının 1. cümlesi, temel hakları kısıtlayıcı kanunlar bakımından, bunların ancak kamu için genel olarak konulabileceğini, münferit olarak konulamıya. cağını emretmektedir. Bonn AY m. 101/I c. 1 ve II ("Tabiî hâkim»; özel mahkemeler ancak "kanunla» kurulabilir) ve benzeri hükümler için de aynı esas geçørlidir; bu konularda da ancak genel kanunî normlar sözkonusu olabilecektir. 


\section{§ 8. Federal Almanya Cumhurfyeti'nin Milletlerüstü Teşkilâtlara Ùye Olmasindan Doğan Anayasal Sorunlar}

Bonn Anayasası çeşitli hükümlerinde, Federal Almanya Cumhuriyeti'nin milletler arasındaki karşılıklı anlayış, devletler hukuku ve milletlerüstü teşkilâtların gelişmesi fikrine bağlı olduğunu tebarüz ettirmektedir. Karşılaştırınız, örneğin, m. 25 (devletler hukukuna bağlılık), m. 26 (saldırganlık savaşı yasağı), Anayasa'nın dibacesi ("Birleșik Avrupa») ve özellikle m. 24/I, II ve III.

Özellikle Bonn Anayasası́nın 24. maddesinin I. fıkrası anayasa teorisi bakımından yorum güçlị̈̆ıi ortaya çıkarmıştır. Adı geçen hüküm şöyledir : Federal Devlet kanun yoluyla egemenlik haklartnı devletlerarası kuruluşlara devredebilir.

Bu hüküm, devletlerarası kuruluşları, şimdiye kadar millî organlar tarafından kullanılagelen egemenlik fonksiyonları ile teçhiz etmek yetkisini vermektedir. Sözkonusu hüküm bir görev yüklememekte, kullanıIması takdire bał̆lı bir yetki getirmektedir. Fakat dibaca, bu temel istikametin genel bir programmı ihtiva etmektedir. Bu yetkinin kapsamı tartışmalıdır; kapsam geniş alındığı takdirde, hukuk devleti aleyhine ve milletlerin kademeli olarak birleşmesi lehine "çok pahal bir avans» verilip verilmediği sorunu ortaya çıkmaktadır.

Bu sebeple en önemli mesele, egemenlik haklarmm ne kapsamda devrinin caiz olacağıdır.

Mevcut görüşlerden biri, anayasal düzenin içine yabancı unsurların girebileceği endişesiyle, sınırı dar tutmaktadır. Bu görüşse göre, ancak mevcut devlet egemenliklerinin devletlerarası organlara «delegasyonu» mümkün olmalıdır. Bu sebeple bu organlar, Anayasa'nın dışında kalan bir tarzda bir faaliyette bulunamamalıdır. lar.

Başka bir görüşe göre ise, sözü geçen 1. fıkra Anayasa çerçevesi dışına çıkılmasına da cevaz vermektedir. Buna göre, devletlerarası teşkilâtlara, Anayasa'ya göre alman organlarının haiz olmadıkları yetkiler de verilebilmelidir. Tabiîdir ki, bu görüște olanlar da bu konuda bazı sinırlar koymaktadırlar. Bu görìs taraftarlarının çoğu halde kabul ettiklerine göre, Anayasa ile devletlerarası düzen arasında gene de hiç değilse «temel teşkil eden kararlarda bir homojenlik" bulunmalı ve muhafaza edilmelidir.

Bu homojenlik esas itibariyle Bonn Anayasası m. 79/II'nin muhtevası ile tetabuk etmelidir. Bundan çıarılan sonuçlardan bi- 
ri, bu tetabukun temel hakların tam bağlayıcı olduğunu ifade etmesidir. Öte yandan ise, temel haklar konusunda milletlerarası asgari bir standardnn garanti edilmesi yeterli görülmektedir.

Daha yeni bir görüșe göre ise, sözü geçen 1. fıkra ne Anayasa'ya yabancı unsurların girmesine, ne de (meşru olarak) Anayasa çerçevesi dışına çıkılmasına elverişlidir. Bu fikra "anayasa vaz'ı" na açık kapı bırakmaktadır. Buna göre, fıkrada sözü edilen yetkiden yararlanmak için büyük bir hareket serbestisi doğmuş olmaktadir.

Kanaatımca, temel hakların bağlayıclı̆̌̆ından kaçınmak mümkün değildir. Her halükârda, iyi anlașıldı̆̆ı takdirde Anayasa'daki temel haklar zaten yeteri kadar sınırlama imkânı da getirmektedir. Mamafih kaçınma imkânı gene de, örneğin, esaslı bazı temel hakların (özellikle m. 19/IV) zaten sadece alman devlet gücüne karş̧ işleyeceği kabul edilecek olduğu takdirde, mevcuttur : $\mathbf{B u}$ ise, esas meseleye bir çözüm getirmiş olmaz. Anayasa'nın geçerlik alanı içerisinde ne zaman bir güç izharına karşı reaksiyon sözkonusu oluyorsa, temel haklar o zaman kendini belli edecektir. Bu sebeple, bu gücün bir alman gücü mü yoksa yabancı bir güç mü olması, bir fark yaratmaz. Alman organları tarafından yetki ile teçhiz edilen yabancı bir güç de aynı nitelikte kabul edilmek gerekir.

Bu sorunun nihaî cevabı, tabiîdir ki, milletlerüstü topluluğun uygulamasının göstereceği gelişme nazarı itibara alınmaksızın verilemez. Çünki alman anayasa hukuku için de geçerli olan husus şudur $\mathrm{ki}$, anayasa hukuku anayasal hayatın gerçeklerine bakılmaksızın bașarllı bir şekilde yürütülemez. 